RESIDENT

\& FELLOW

SECTION

Section Editor

Mitchell S.V. Elkind,

MD, MS

Parayil Sankaran Bindu, DM

Sanjib Sinha, DM

Arun B. Taly, DM

Rose Dawn Bharath, DM

Address correspondence and reprint requests to Dr. Sanjib Sinha,

Department of Neurology,

National Institute of Mental Health and Neurosciences, Bangalore 560

029, Karnataka, India

sanjib_sinha2004@yahoo.co.in

\title{
Teaching NeuroImages: Hemimegalencephaly in linear nevus sebaceous syndrome
}

Figure $1 \quad$ Patient with linear nevus sebaceous syndrome

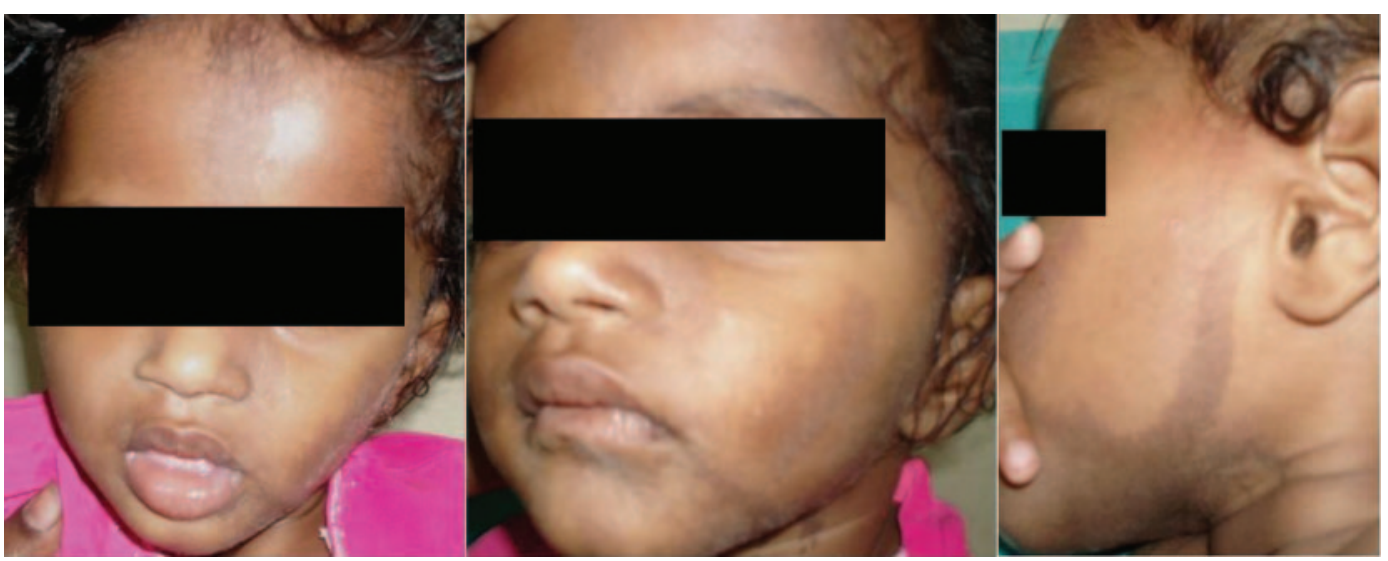

Facial nevus on the left side of the face with facial asymmetry.

A 15-month-old girl presented with developmental delay, intractable right focal motor seizures, hyperpigmented patch on the left side of the face, facial asymmetry, and right hemiparesis (figure 1). A diagnosis of linear nevus sebaceous syndrome (LNSS) was considered. Brain MRI revealed hemimegalencephaly (figure 2). EEG showed spike/wave discharges in left occipital leads. Ophthalmologic and skeletal evaluation were normal.

LNSS is a rare, sporadic neurocutaneous syndrome characterized by linear sebaceous nevus of Jadassohn, mental retardation, and seizures. ${ }^{1}$ Hemimegalencephaly is a major feature of this syndrome. ${ }^{2}$ Skeletal and ocular involvement occur in up to $68 \%$ of the patients. Intractable seizures may necessitate epilepsy surgery.

\section{REFERENCES}

1. Menascu S, Donner EJ. Linear nevus sebaceous syndrome: case reports and review of the literature. Pediatr Neurol 2008;38:207-210.

2. Sarnat LF. Hemimegalencephaly: part 1: genetic, clinical, and imaging aspects. J Child Neurol 2002;17:373-384.

Figure 2 MRI of the patient

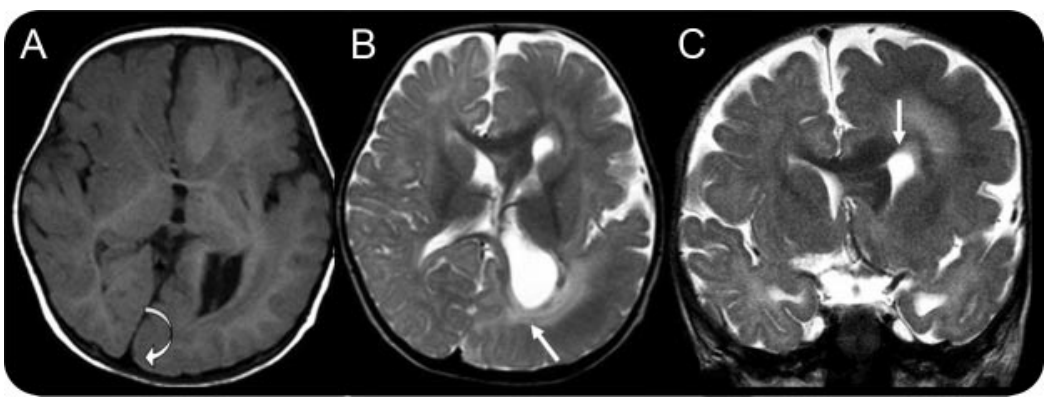

Brain MRI demonstrates the presence of hemimegalencephaly with an enlarged left hemisphere, colpocephaly ( $A, B)$, midline shift of a dysplastic occipital lobe (occipital sign, $A, B$ ), white matter signal intensity changes $(B, C)$, and straightened frontal horn (arrow, C).

From the Departments of Neurology (P.S.B., S.S., A.B.T.), Neuroimaging and Interventional Neuroradiology (R.D.B.), National Institute of Mental Health and Neurosciences (NIMHANS), Bangalore, India.

Disclosure: The authors report no disclosures. 


\section{Neurology}

Teaching NeuroImages: Hemimegalencephaly in linear nevus sebaceous syndrome Parayil Sankaran Bindu, Sanjib Sinha, Arun B. Taly, et al.

Neurology 2010;74;e27

DOI 10.1212/WNL.0b013e3181d0ccb7

This information is current as of February 22, 2010

\section{Updated Information \&} Services

References

Subspecialty Collections

Permissions \& Licensing

Reprints including high resolution figures, can be found at: http://n.neurology.org/content/74/8/e27.full

This article cites 2 articles, 0 of which you can access for free at: http://n.neurology.org/content/74/8/e27.full\#ref-list-1

This article, along with others on similar topics, appears in the following collection(s):

Developmental disorders

http://n.neurology.org/cgi/collection/developmental_disorders MRI

http://n.neurology.org/cgi/collection/mri

Other neurocutaneous disorders

http://n.neurology.org/cgi/collection/other_neurocutaneous_disorders

Information about reproducing this article in parts (figures,tables) or in its entirety can be found online at:

http://www.neurology.org/about/about_the_journal\#permissions

Information about ordering reprints can be found online:

http://n.neurology.org/subscribers/advertise

Neurology ${ }^{\circledR}$ is the official journal of the American Academy of Neurology. Published continuously since 1951, it is now a weekly with 48 issues per year. Copyright . All rights reserved. Print ISSN: 0028-3878. Online ISSN: 1526-632X.

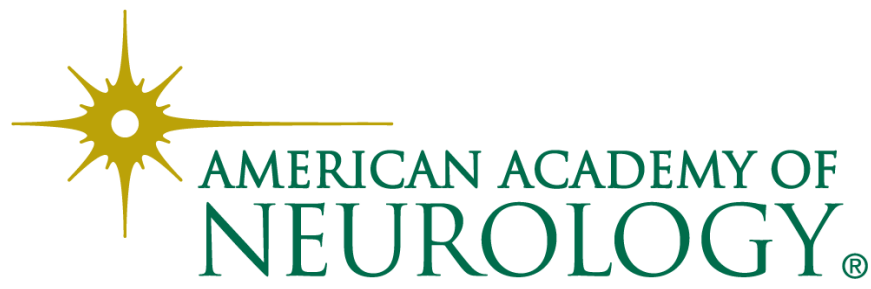

